\title{
Copyright and Social Movements in Late Nineteenth-Century America
}

Steven Wilf

University of Connecticut School of Law

Follow this and additional works at: https://opencommons.uconn.edu/law_papers

Part of the Intellectual Property Law Commons, Law and Society Commons, and the Legal History Commons

\section{Recommended Citation}

Wilf, Steven, "Copyright and Social Movements in Late Nineteenth-Century America" (2011). Faculty Articles and Papers. 42. https://opencommons.uconn.edu/law_papers/42 


\section{HEINONLINE}

Citation: 12 Theoretical Inq. L. 1232011

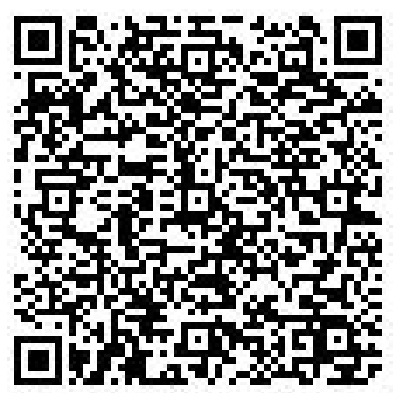

Content downloaded/printed from

HeinOnline (http://heinonline.org)

Mon Aug 15 17:35:04 2016

-- Your use of this HeinOnline PDF indicates your acceptance of HeinOnline's Terms and Conditions of the license agreement available at http://heinonline.org/HOL/License

-- The search text of this PDF is generated from uncorrected OCR text.

-- To obtain permission to use this article beyond the scope of your HeinOnline license, please use:

https://www.copyright.com/ccc/basicSearch.do?

\&operation $=$ go\&search $\mathrm{Type}=0$

\&lastSearch $=$ simple\&all=on\&titleOrStdNo=1565-1509 


\title{
Copyright and Social Movements in Late Nineteenth-Century America
}

\begin{abstract}
Steven Wilf*
The cultural turn in copyright law identified authorship as a rhetorical construct employed by economic interests to strengthen claims to property rights. Grassroots intellectual property political movements have been seen as both a means of countering these interests' everexpanding proprietary control of knowledge and establishing a more public regarding copyright system. This Article examines one of the most notable intellectual property political movements, the emergence of late nineteenth-century agitation to provide copyright protection for foreign authors as a social movement. It places this political and legal activism within the larger framework of Progressive Era reform. During this period, activists promoted the idea of the public - and not simply the author - as primary to the workings of American copyright. The framing of the purposes of copyright, the appeal to a broader public, and the complex negotiations surrounding the passage of an international copyright act after a long period of gestation was formative to the creation of modern United States copyright law. Ironically, the movement for international copyright also sharpened the identification of interest groups. The first modern American comprehensive copyright legislation, the 1909 Copyright Act, was drafted by gathering together these groups for negotiations
\end{abstract}

* Joel Barlow Professor of Law, University of Connecticut School of Law and Microsoft Fellow in Law, Property, and the Economic Organization of Society, The Program in Law and Public Affairs at Princeton University. I would like to thank the participants at the Conference on Copyright Culture, Copyright History held by the Cegla Center at Tel Aviv University, January 2010, the Law Faculty of the University of Vienna, and the Workshop of the American Studies Program at Princeton University for their discussion of an earlier version of this Article. I especially appreciate the comments of Michael Zakim, Guy Pessach, and Michael Birnhack. Research for this Article relied upon materials located in the manuscript divisions of the University of Pennsylvania Library and the New York Public Library. 
remarkably similar in style to those which led to the protection of the rights of foreign authors - but which would strongly embrace a proprietary model.

\section{INTRODUCTION}

Implementing the Economic Commission's European Copyright Directive, Sweden enacted the Copyright Act of 2005, which imposed tough enforcement for copyright infringement. In the same year, Sweden's Piratpartiet (Pirate Party) was founded. By portraying copyright as a feature of an emerging surveillance culture, the Pirate Party set itself at odds with the government's adoption of a digital rights management system (DRM) and positioned itself as the defender of a fundamental right to swap music files on the internet. This new party identified three aims: copyright reform, including the legalization of file sharing and noncommercial copying; the abolition of the patent system; and strengthening respect for personal privacy. ${ }^{1}$ After the Swedish government's May 31, 2006 massive raid on Pirate Bay, a peer-to-peer file transfer site originally begun by piracy activists, supporters organized street protests. The combination of traditional grassroots activism and new technologies for exchanging knowledge, Pirate Party supporters claimed, could revitalize European political life.

Sweden's cyber-swashbucklers are only one example of burgeoning grassroots organizations which recently have emerged around issues of intellectual property. Pirate parties exist in nearly twenty countries. The Open Source software movement and various novel attempts to carve out exceptions to the proprietary model, such as the Creative Commons or the Electronic Frontier Foundation, speak to the vibrant politics of knowledge.

This Article is about how citizens mobilize to transform prevailing intellectual property rules and what new normative worlds they envision. By focusing on a late nineteenth-century American movement dedicated to reconfiguring intellectual property rights - an urban Progressive enlistment of authors, readers, and concerned citizens seeking to extend copyright protection to foreign authors - it shows how copyright was intimately bound up with political contestation. More importantly, from a normative point of view, it underscores the possibilities and pitfalls of relying upon social movements to alter the terrain of contemporary intellectual property

1 See The Pirate Party, The Pirate Party Declaration of Principles, http://docs. piratpartiet.se/Principles\%203.2.pdf (last visited July 1, 2010). 
protection. The idea of popular mobilization has considerable allure. This is true for both advocates of a more public-regarding understanding of intellectual property and for those who use mobilization to lay claim to judicially-enforceable rights in other fields of law. As we see from the American experience with copyright agitation of the $1880 \mathrm{~s}$ and $1890 \mathrm{~s}$, however, the endgame for such movements can seriously depart from the expectations of their founders.

Looking at social movements, moreover, allows us to situate legal change in its social context. The cultural turn in intellectual property scholarship has long recognized the importance of the social construction of categories such as the romantic author or the heroic inventor. ${ }^{2}$ Indeed, these pervasive descriptions often have been presented like a Moliè re drama. Interest groups prod these idealized figures onto the stage as claims are made for expanding the scope of proprietary rights. Soon other dramatis personae might be seen gathering about. Examining the earliest modern copyright law, the Statute of Anne (1710), for example, we see references to the author's family made destitute by reprinting without the payment of royalties. ${ }^{3}$ Even books, the child of the author's invention, might be personified as a metaphor. Orphan

2 See Keith Aoki, Adrift in the Intertext: Authorship and Audience 'Recoding' Rights, 68 CHI.-KENT L. REV. 805 (1993); Peter Jaszi, On the Author Effect: Contemporary Copyright and Collective Creativity, 10 CARDOZO ARTS \& ENT. L.J. 293 (1992); James Boyle, A Theory of Law and Information: Copyright, Spleen, Blackmail, and Insider Trading, 80 CAL. L. REv. 1413 (1992); Peter Jaszi, Toward a Theory of Copyright: The Metamorphoses of 'Authorship,' 41 DukE L.J. 455 (1991); Robert H. Rotstein, Beyond Metaphor: Copyright Infringement and the Fiction of the Work, 68 CHI.KENT L. REV. 725 (1993); Martha Woodmansee, On the Author Effect: Recovering Collectivity, 10 ARTS \& ENT. L.J. 279 (1992); see also OF AUTHORS AND ORIGINS: ESSAYS ON COPYRIGHT LAW (Brad Sherman \& Alain Strowel eds., 1994); THE CONSTRUCTION OF AUTHORSHIP, TEXTUAL APPROPRIATION IN LAW AND Literature (Martha Woodmansee \& Peter Jaszi eds., 1994). For a related philosophical inquiry, see LIOR ZEMER, THE IDEA OF AUTHORSHIP IN COPYRIGHT (2007); Jeremy Waldron, From Authors to Copiers: Individual Rights and Social Values in Intellectual Property, 68 CHI.-KENT L. REV. 841 (1993) (noting that cultural assumptions about authorship inform how we think about the legal issues of copying). For an exploration of authorship in trademarks, see Steven Wilf, Who Authors Trademarks?, 17 CARDOZO ARTS \& ENT. L.J. 1 (1999). Most recently, Oren Bracha has explored the construction of the trope of the heroic inventor in patent law, Oren Bracha, Geniuses and Owners: The Construction of Inventors and the Emergence of American Intellectual Property, in TRANSFORMATIONS IN AMERICAN LEGAL HISTORY 369 (Daniel W. Hamilton \& Alfred L. Brophy eds., 2009).

3 Copyright Act of 1709,8 Ann., c. 19 (Eng.). 
works would later become the metaphoric term for those progeny bereft of an attentive owner. ${ }^{4}$ Courts and legislatures have deployed these figures - the romantic author and his doppelgänger in the white laboratory coat, the heroic inventor - at the behest of interest groups to extend the scope of intellectual property protection and to legitimize the vesting of knowledge entitlements in proprietary personalities with claims of ownership. Whether the terms used are propertization, commodification, enclosure, or - as James Boyle calls it - the development of "the maximalist rights culture," the result is an ever-shrinking public domain. ${ }^{5}$

Such narratives exposing the interest groups lurking behind conceptions of the romantic author have a decidedly teleological cast. Following a plot line which looks remarkably like literature's new historicism meets rational choice theory, the construction of authorship model assumes that literary images - and, indeed, copyright lobbying - were intended to benefit large-scale owners of knowledge capital. This Article seeks to turn the authorship Grundmetapher on its head. It argues that social movements in late nineteenth-century America began with flesh and blood historical actors, and ended up with unexpected consequences. Out of a campaign to pass international copyright legislation emerged a new interest group politics of copyright. Self-identified interest groups, the Article argues, are historical constructions. Although self-interest - concerns with pecuniary and status gains - is always a feature of carving out property rights, interest groups, like other associations, coalesce at specific historical moments.

By examining the debate over the extension of copyright protection to foreign authors as a case study in the contested history of intellectual property, this Article recovers both the role of the public in forging intellectual property norms and the limits of its capacity to introduce a public-oriented copyright regime. It argues that the late nineteenth-century international copyright social movement with its focus on the public good had two surprising outcomes. First, this movement proved to be the midwife of a new interest politics of intellectual property, which was critical in shaping the 1909 Copyright Act. Ironically, the international copyright movement, secondly, had the effect of marginalizing the American role in emerging systems of copyright global governance.

Part I, Why Social Movements?, explains how examining popular

4 William Patry, Moral Panics and the Copyright Wars 69-71 (2009).

5 Robert Merges, One Hundred Years of Solicitude: Intellectual Property Law 19002000, 88 CAL. L. REV. 2187 (2000). For a classic tale of expansion, see NEIL NetANEL, COPYRIGHTS PARADOX (2008); James Boyle, A Manifesto on WIPO and the Future of Intellectual Property, DukE L. \& TECH. REV., Aug. 9, 2004, at 1, 8. 
mobilization agitating for the alteration of intellectual property rights can reorient our overarching historical narratives about intellectual property. It suggests that we need to shift from a model of the expansion of rights to understanding the importance of contestation. Even the historical source material - polemical, and even highly speculative proposed schemes, rather than purely cases and statutes - must be different when we examine social movements. Part II, Americanizing International Copyright, describes the historical strands in the early nineteenth century which will provide the grounding for the late nineteenth-century movement. These strands were both domestic - the attempt to create an intellectual infrastructure for a fledgling republic - and rooted in international law.

Part III, International Copyright as a Reform Movement, situates the proposals for providing protection to foreign authors within the skein of Progressive Era reform. It interrogates how intellectual property associations grappled with notions of property and the moral imperative to guard against theft, Progressive conceptions of good government, international obligations, and how the policy of providing "cheap books" as a means to promote the ideal of an informed democratic citizenry influenced understandings of copyright. Part IV, Conversion on the Road to Berne, describes the calls for the United States to shift from a territorial conception of copyright to a new world order for the regulation of literary property. This section unpacks the fissures in the international copyright movement that emerged as attempts to make international copyright protection part of American law failed. Part V, Negotiating Copyright examines the passage of the Chace Act of 1891, which provided for international copyright protection for foreign authors in the United States. It traces the shift as an array of international copyright movement advocates, who often articulated their positions in competing rights language were forced to bridge their differences in order to negotiate an agreed upon strategy for the successful enactment of legislation. These negotiations took place in the shadow of possible legislative action.

Part VI, From Social Movement to Interest Politics, shows how interest groups were forged in the course of mobilizing popular support for international copyright protection. By the time of the passage of the 1909 Copyright Act, America's first truly modern comprehensive copyright legislation, the organizations involved in calling for new copyright law had shifted from public-oriented reform associations to those representing fairly narrow economic interests. It describes how the making of the 1909 Act relied upon lessons derived from the struggle over international copyright. In drafting this new legislation, however, the process was directed by government officials who identified interests groups and called them together as a kind of miniature legislature to settle differences. The 
concluding section, Part VII, discusses the normative lessons that might be drawn from late nineteenth-century copyright social movements. This section, Literary Culture Without Borders, suggests that social movements sometimes turn out very differently than we expect. This is especially true for late nineteenth-century copyright mobilization. Ironically, public-regarding copyright reform associations served as the midwives to blatant interest groups involved in framing of copyright legislation. The particular negotiated settlement of the Chace Bill of 1891, with its inclusion of a clause requiring foreign authors to print their books within the borders of the United States in order to acquire copyright protection, in fact had the opposite effect than might have been anticipated - distancing America from the Berne framework of international copyright. The final irony, however, might well be that those interested in public-regarding copyright reform have written a history of the inexorable expansion of copyright while ignoring a past filled with earlier forms of grassroots politics.

\section{Why Social Movements?}

Too often, the master narrative of intellectual property law in America focuses upon relentless propertization and commodification. Intellectual property law in America, however, was forged in contestation. Contestation takes many different forms. It includes public debates about the nature and expanse of intellectual property, attempts at statutory reform in Congress - even when such reform has little chance of success - through proposed statutes, and widespread infringement. In other words, these are all "legal" responses to existing law, insofar as they are part of a broadly legal discourse about the core aspects of an area of law. A broad social history of contestation should encompass questions about the back and forth debates over the scope of intellectual property law. How did these debates emerge from the usual business of establishing a legal regime? How did social groups mobilize to influence the boundaries of knowledge protection? What strategies were employed? And how did these alter the emergence of intellectual property law in America?

As a form of contestation, social movements provide a glimpse of the consciousness behind the response to existing intellectual property norms. Such movements test the plasticity of legal conventions, identify core ideas grounding legal doctrine, and frame legal arguments in order to expand their base beyond core constituencies. Our focus will be upon how citizens imagined doctrine - not how doctrine imposed legal categories upon them. In the course of their creation of associations intimately concerned 
with the granularity of intellectual property legal rules, ordinary citizens conjured up the public, endowing users, who demanded cheap books as a form of education, and the moral public actor with their own metaphorical personae. While interest groups certainly lobbied or litigated for their own purposes, the definition of who constituted an interest group was also a social construction shaped by civic associations.

Is this a story of interest groups or social movements? How do we distinguish one from the other? The hallmarks of a social movement, as opposed to an interest group, consist of broad-based mobilization, ideological claims grounded upon a capacious understanding of the public good, and an organizational framework resembling those of civic organizations. Interest groups seek to influence public policy for the purpose of rent-seeking private gain. Such groups might be industry, consumer, or workers' groups which exert influence in the process of bargaining for resources. In contrast, social movements are concerted and sustained extra-official actions aimed at effecting social change. ${ }^{6}$ They reflect more self-consciousness than simply shared belief, more cooperative organization than spontaneous protest, and more broadly based concerns than garden variety interest groups. ${ }^{7}$

Copyright social movements often identify themselves as operating within a constitutional ambit. In the American context, "the people themselves" are a constitutive part of intellectual property's doctrinal landscape. The United States Constitution establishes a requirement that copyright and patent law "promote the progress of science and the useful arts." ${ }^{8}$ This mandate has been interpreted as Congress serving as a proxy for identifying the public good, and establishing federal intellectual property regimes to further this goal, rather than a direct public involvement in the process. It is important, then, to understand how a specifically American legal tradition evolved whereby the public came to demand a place at the table for setting the metes and bounds of copyright law.

6 JeFF GoOdwin \& James M. JASPeR, The Social Movements Reader: CaSes AND CONCEPTS 3-8 (2009); MiCHAEL MCCANN, LAW AND SOCIAL MOVEMENTS, at xi-xxvi (2006); Alan Hunt, Rights and Social Movements: Counter-Hegemonic Strategies, 17 J. L. \& SOC'Y 309, 309-28 (1990).

7 See, e.g., William N. Eskridge, Some Effects of Identity-Based Social Movements on Constitutional Law in the Twentieth Century, $100 \mathrm{MicH}$. L. REv. 2062 (2002); William E. Forbath, The New Deal Constitution in Exile, 51 DUKE L.J. 165 (2001); Reva B. Siegel, Constitutional Culture, Social Movement, Conflict and Constitutional Change: The Case of the De Facto ERA, 94 CAL. L. REV. 1323 (2006).

8 U.S. CONST. art. $1, \S 8$. 


\section{Americanizing International Copyright}

It took almost fifty-four years for American advocates of legislation to secure U.S. copyright protection for foreign authors. ${ }^{9}$ The first American legislation providing for international copyright was introduced in the Congress by Henry Clay in $1837 .{ }^{10}$ Yet not until the International Copyright Act of 1891, more commonly known as the Chace Act, two generations after the earliest proposals, could British authors regularly obtain royalties for the printing of their work in America. To a large extent, the ultimate success of international copyright agitation relied upon such social movement associations as the American Copyright League, founded in 1884, which mobilized a broad public campaign to provide proprietary rights to foreign authors. In order to understand the makings of the later international copyright movement, it is critical to examine its roots in the earlier part of the nineteenth century - as Americans sought to construct both domestic and international rationales for recognizing literary property rights across national boundaries.

Late nineteenth-century reformers, including members of the American Copyright League, were well aware of the legacy of earlier failed attempts. George Palmer Putnam, whose 1840s writings on international copyright were critical for framing the position of the publishing industry, was the father of George Haven Putnam, whose book The Question of Copyright was the most important statement of the American Copyright League's position. Henry C. Carey, author of the Reconstruction Era Letters on International Copyright, was the uncle of Henry Charles Lea, who ultimately drafted the successful Chace Act. Carey's protectionist, pro-cheap books, and antiinternational copyright arguments were resurfacing in the late nineteenth century in a variety of forms, and Lea, himself a proponent of international copyright, would have to contend with them. ${ }^{11}$

International copyright protection was a notable departure from the original constitutional understanding of copyright as a territorial right. The 1790 Federal Copyright Act explicitly stated that it would not constrain the importation, sale or publishing of any works by non-citizens Indeed,

9 George Haven Putnam, The Question of Copyright, at xvii (New York, G.P. Putnam's Sons 1896).

10 S. Doc. No. 24-179 (1837) with S.223, 24th Cong. (2d. Sess. 1837); RICHARD ROGERS BOWKER, COPYRIGHT: ITS HISTORY AND ITS LAW 346-47 (1912).

11 AdRIAN JOHNS, PIRACY: THE INTELLECTUAL PROPERTY WARS FROM GUTENBERG TO GATES 309-25 (2009), discusses Carey's attack on copyright, identifying copyright with placing limitations on "the national mind." 
United States copyright law might be said to have facilitated the creation of a culture of reprinting inexpensive, mostly British, works. In 1820, Samuel Goodrich, an American publisher, estimated that approximately seventy percent of American book manufacture was based upon British authors. ${ }^{12}$ While land as a form of property in the early Republic was frequently celebrated as the grounding for autonomous civic participation in a republican system of governance, intellectual property lacked any similar purpose. Instead, copyright was sometimes seen as counter to participatory democracy. ${ }^{13}$ Jacksonian publicist William Leggett, for example, called intellectual property "artificial rights." Celebrating cheap editions of books for diffusing literature to all classes of society, he sought to annul copyright. Language, Leggett insisted, is "the common property of all mankind."14 Questions were raised about who benefits from these grants of exclusive rights. Intellectual property was increasingly considered with issues of economic development, monopoly control, international commerce and tariffs, and the division of property.

Given this ambivalence towards copyright, it was not surprising that from the beginnings of federal copyright in 1790 to the passage of the Chace Act of 1891, the United States failed to protect foreign copyrights. Such a policy was also consistent with parallel developments in United States patent law. The first United States patent acts encouraged the technological transfer of knowledge from Britain to the new republic by failing to provide protection for British inventions. During the debates over the 1790 Patent Act, Congress considered establishing patents of importation, which would provide a limited monopoly to those bringing innovative technology to America. ${ }^{15}$ Among the supporters of patents of importation was George Washington, who urged in his 1790 State of the Union address that Congress should grant "effectual encouragement as well to the introduction of new and useful inventions from abroad, as to the exertions of skill and genius in producing them at home." Hamilton even proposed bestowing bounties on

12 Catherine Seville, The Internationalisation of Copyright law: Books, BUCCANEERS AND THE BLACK FLAG IN THE NINETEENTH-CENTURY 158 (2006).

13 Gregory S. Alexander, Commodity and Propriety: Competing Visions of PROPERTY IN AMERICAN LEGAL ThOUGHT 1776-1970, at 21-126 (1997).

14 William Leggett, Plaindealer (1837), reprinted in Democratick Editorials: Essays in Jack sonian Political Economy 391 (Lawrence H. White ed., 1984).

15 Doron S. Ben-Atar, Alexander Hamilton's Alternative: Technology Piracy and the Report on Manufactures, 52 WM. \& MARY Q. 389, 411 (1995); see also DORON S. Ben-Atar, Trade Secrets: Intellectual Piracy and the Origins of American INDUSTRIAL POWER (2004). 
such individuals. ${ }^{16}$ While these approaches were not adopted, they do suggest the willingness to encourage what today might be considered intellectual property piracy. ${ }^{17}$

The initial response to America's citizenship — and residency-based copyright regime came from the British. In 1836, British publishers and a transatlantic list of authors petitioned Congress to provide protection for non-American writers. The authors argued that their works were often altered without their consent. An 1838 Parliamentary statute further encouraged an international regime by providing for English protection to authors of books first published in foreign countries where reciprocal protection was provided by the authors' own governments. ${ }^{18}$ It created an opening for negotiations with the United States and other nations, but the statute did not itself establish international protection. ${ }^{19}$ By 1854 , every country in the world, with the exception of the United States, Russia, and the Ottoman Empire, had adopted international copyright founded upon a system of reciprocity. ${ }^{20}$

The dilemma of America's lack of extension was obvious to one of the leading political figures of the antebellum period, Henry Clay. A Kentucky Congressman and Senator, Clay was the architect of the Whig

16 Jefferson admitted that bounties were useful instruments of economic development, although he was concerned about abuse. He believed that the power to issue them had been delegated not to the federal government, but to state governments, "whose local information renders them competent judges of the particular arts and manufactures for which circumstances have matured them." THOMAS JEFFERSON, NOTES ON THE CONSTITUTIONALITY OF BOUNTIES TO ENCOURAGE MANUFACTURING (1792), reprinted in 23 THE PAPERS OF THOMAS JEFFERSON 172, 172-73 (Charles T. Cullen ed., 1990); Edward C. Walterscheid, Patents and Manufacturing in the Early Republic, 80 J. Pat. \& TRademark OfF. SOC'y 855, 862 (1998).

17 Nevertheless, it is important to see intellectual property piracy within its historical context, and not to impose this construct from contemporary perspectives.

18 International Copyright Act, 1838, 1 \& 2 Vict., c. 59 (Eng.).

19 SEVILLE, supra note 12 , at 25 . As Seville points out, the Act was poorly drafted and no agreements were ever signed under its terms.

20 Edward G. Hudon, Mark Twain and the Copyright Dilemma, 52 A.B.A. J. 56 (1966). On the American international copyright issue in general, see JAMES J. Barnes, Authors, Publishers, And Politicians: The Quest for An ANgloAMERICAN COPYRIGHT AGREEMENT: 1815-1854 (1974); and ALBERT J. CLARK, THE MOVEMENT FOR INTERNATIONAL COPYRIGHT IN NINETEENTH-CENTURY AMERICA (1960). Meredith L. MCGill, American Literature and the Culture of REPRINTING 1834-1853 (2003) remains the best work on the effect of lack of protection for foreign authors on the literary cultural production. See also ROBERT J. Zboray, A Fictive People: Antebellum Economic Development and the AMERICAN READING PUBLIC (1993). 
Party's American System, which fostered the construction of a national infrastructure to bind together the country's different regions and which promoted high tariffs to shield America's nascent industries from foreign competition. The system included such internal improvements as canals, ports, and railroads as well as a national bank. Clay's interest in copyright, and specifically the international copyright issue, followed the contours of Whig ideology. A cultural infrastructure of books, newspapers, and pamphlets would allow communication across the continent's vast expanse, and promote shared national values. Granting copyright privileges to foreign authors would raise the price of their books, and therefore assist American authors by leveling the playing field in the publishing industry between domestic authors and those writing abroad. Protection of non-American writers was essentially a way of raising a tariff on foreign books. By shielding the domestic market from British authors, Whigs believed that a trans-regional American literary culture would flourish. ${ }^{21}$

It is ironic that the beginnings of America's participation in international copyright protection should have been predicated upon a project to create a specifically American national identity. As a result of Clay's agitation, copyright was linked to deep fissures among the different regions of the country over tariff issues. Clay three times unsuccessfully presented an international copyright bill to Congress. In 1839, he already realized the limits of direct action in Congress. Clay sought a limited set of protections for British and French authors as a form of "reciprocal justice." In the debates, he directed arguments towards different regional constituencies. For the Northeast, he made the typical protectionist claim that inexpensive editions of foreign authors' works undercut the creation of a domestic literary culture. For the South, which was chaffing under high tariffs for manufactured goods, he compared literary expression to a "bale of merchandise," and claimed that raw materials were being subject to an unfair tariff. Instead of serving to unify the nation, pro-international copyright was compelled to confront regional difference. Nevertheless, Clay hoped that public mobilization in support of these principles, or "enlightened public opinion" in his words, would allow for copyright reform. ${ }^{22}$ This turn towards the public had two major effects. First, legal thinkers addressed the conceptual underpinnings of

21 Seville, supra note 12, at 76-108 (describing the domestic political context for international copyright reform).

22 Letter from Henry Clay to Francis Lieber (June 19, 1839), in 9 THE PAPERS OF HENRY Clay 327 (Robert Seager ed., 1988); Frank Freidel, Lieber's Contribution to the International Copyright Movement, 8 HUNTINGTON LiBR. Q. 200, 201 (1945). 
intellectual property regimes; and, second, a variety of public voices were brought into these debates.

Clay turned to Francis Lieber, an American-German jurist who is today most widely known as a pioneering figure in establishing rules of conduct for troops in wartime. By enlisting an international jurist for his American System project, Clay repositioned international copyright protection as an international obligation rather than as a matter of tariff policy. Lieber's 1840 pamphlet, On International Copyright, claimed that America's failure to provide a property right in foreign literary property violated fundamental aspects of the law of nations. According to Lieber, copyright was a natural right: "If there exists any species of property not made by government, but existing by spontaneous right, and which requires only to be acknowledged by way of protection on the part of government, it is literary property." In a lengthy essay on the connection between copyright and property published in 1829 , Lieber called literary property a species of property which does not impinge upon the rights of others. Literary property benefits the country more than other property, these rights are grounded upon Lockean ideas of property rights acquired through labor, and the theft of mental production is dishonorable. While there has always been a property right in literary property, Lieber argued, it was only with the cheap printing of books that this right became ripe for exploitation by authors. But Lieber's argument was really about fundamental fairness, and his sometimes rather highflying rhetoric suggests that international copyright was fundamentally a rule of law issue: "Barbarous or degenerate nations treat one another like ruffians or blackguards; civilized and elevated nations like gentlemen."23

The other part of the international copyright campaign was waged by American authors such as James Fennimore Cooper. Cooper admitted that copyright was exclusionary and had more than a whiff of monopoly. Nevertheless, he raised the larger problem of the cultural dependency of Americans upon British foreign opinion. ${ }^{24}$ As Martin Buinicki points out, Cooper and later literary proponents of international copyright — including

23 Francis LieBer, On InTERNATIONAL Copyright 17-19, 53 (London, Wiley \& Putnam 1840). On Lieber's role in constructing an American posture towards international law, see MARK WESTON JANIS, AMERICA AND THE LAW OF NATIONS 1776-1939, at 117-19 (2010). See, e.g., Law of Copy Right, 1 U.S. INTELLIGENCER \& REV., Mar. 1829, at 66.

24 Martin Buinicki, Negotiating Copyright: Authorship and the Discourse of LITERARY PROPERTY IN NINETEENTH-CENTURY AMERICA 16-19 (2005). Of course, the absence of reciprocity caused injury to well-known American authors, who were unable to reap profit from sales of their work in Britain. 
Walt Whitman, Harriet Beecher Stowe, and Mark Twain - had to define their roles to readers. They sought protection for British authors as part of a broader claim on readers as a social constituency which could be mobilized for political purposes. Authors and readers shared common sentiments, a communicative landscape of cultural references, a mutual recognition of the importance of the literary enterprise beyond purely pecuniary motives, and what has been called an "ideology of literacy" — the notion that reading is essential to fulfilling the duties of citizenship. ${ }^{25}$ In this regard, the campaign for international copyright played a constitutive role in constructing the meaning of authorship. Moreover, authors saw themselves as part of a transatlantic society of letters, where authors in one country pursue the rights of authors from abroad. ${ }^{26}$

Yet there was also strong resistance to international copyright. Jacksonian Democrats such as Leggett argued that the absence of copyright protection for foreign authors promoted the publication of inexpensive editions. In 1838 , the Patent Commission issued a report against international copyright on the following grounds: (1) the effect on numerous workers and families who could not afford more expensive books; (2) the argument that cheap editions in the United States, where population was sparse, served the same function of dissemination as public libraries in the British Isles. ${ }^{27}$ In other words, not extending copyright to foreign authors furthered the fundamental purposes of copyright — one of which, as defined by the Patent Commission, was the dissemination of literary property as a means of promoting a democratic society. Again, the debates over the scope of property were intimately linked to the discourse of identifying the philosophical and policy grounding for the legal regulation of knowledge.

The rise of the industrial book during this period, based upon printing

25 Scott E. Casper, Introduction to The History of the Book in America: The InDUSTRIAL BooK 1840-1880, at 1, 4 (Scott E. Casper, Jeffrey D. Groves, Stephen W. Nissenbaum, \& Michael Winship eds., 2007).

26 The emergence of a transatlantic society of letters might be seen throughout the nineteenth century in the call for international copyright, the exchange of literary material, and the performative aspect of British authors embarking on speaking tours. Americans participated in some of the international authors' organizations which were formed in the last quarter of the century. George Bancroft, for example, represented the United States at the Société des Gens Lettres at the 1878 Exposition Universelle in Paris. However, the American notion of a transatlantic literary culture often took informal forms. DAVID SAUNDERS, AUTHORSHIP AND COPYRIGHT 169-70 (1992).

27 Report from the Commission of Patents and the Patent Office, S. Doc. No. 25-494, at 4-5 (2d. Sess. 1838). 
from plates - what Trish Loughran calls "print capitalism" — created a new player in the copyright debates, the large-scale publishing house. ${ }^{28}$ Facing intense competition, publishers claimed that the mass production of texts was a form of public service. Nevertheless, the competitive jostling over unprotected British editions led to a constitutive construction of their own common identity. During the 1820s and 1830s, some American firms paid for advanced sheets of British works. An informal, extralegal system, called "courtesy of the trade," meant that American publishers refrained from reprinting a work already published by another American publisher. ${ }^{29}$ Yet the very complexity of the book market led to widely different positions among publishers. Some saw the production of cheap editions without any scruples towards other [foreign] publishers as an economic lifeline, some specialized in obtaining contacts with British publishers and authors to establish "courtesy of the trade," and some viewed the inexpensive reprinting of the works of British writers as undercutting the publication of promising American authors.

In 1840, George Palmer Putnam published a pamphlet which bemoaned the defect of the lack of statutory protection for both the publishing industry and the people at large. ${ }^{30}$ But clearly this was a minority view among publishers, and an organization was needed to mobilize public sentiment in favor of international copyright. In 1843, the American Copyright Club was founded, which expressed the gamut of comments shared by pro-international copyright proponents, including moral arguments against piracy, the harm to both American and British authors, the mutilation of literary works, and the damaging effect of dependency upon British authors on the emergence of American literary production and on American culture as a whole. ${ }^{31}$

Most significantly, the American Copyright Club sidestepped legislative lobbying to address citizens directly. The split between publishers assumed a regional aspect. By the early $1850 \mathrm{~s}$, New York publishers were working together to present a draft treaty for international copyright to the Secretary of

28 Trish loghran, The Republic in Print Culture in the Age of U.S. Nation BUILDING 1770-1870, at xviii (2007); Michael Winship, Manufacturing and Book Production, in The History of THE BoOk in America: The Industrial BoOk 1840-1880, supra note 25 , at 40, 40-58.

29 SEVILLE, supra note 12, at 29.

30 George Palmer Putnam, An Appeal to American Authors and the American Press in Behalf of International Copyright (New York, Wiley 1842).

31 American Copyright Club, An Address to the People of the United States 1 (New York, American Copyright Club 1843). 
State, Edward Everett. ${ }^{32}$ Philadelphia publishers, through a series of petitions and a pamphlet published in 1853 by economist Henry C. Carey, launched an opposition to international copyright that not only attacked extending protection to foreign authors, but critiqued the very notion of copyright. A proponent of laissez-faire capitalism, Carey saw intellectual property as expanding in both the dimension of time, through the extension of terms, and, with calls for international copyright, in space. Anti-extension forces enlisted labor, concerned about whether the importation of British books might endanger jobs in America, while a variety of organizations, such as the International Copyright Association (1868), were founded to bring authors and publishers under one roof.

By the 1860s, relations between publishers worsened as a result of competitive pressures and competing ways of viewing the book market. In the $1860 \mathrm{~s}$, the customary self-help mechanism for bringing order to the publication of British editions, "courtesy of the trade," the promise of American publishers not to bring out a competing edition of an English book after its release in America, began to break down. ${ }^{33}$ Some publishers of reprint editions failed to recognize this extralegal claim to an exclusive right to the first foreign edition, and printed cheap versions of these books. Small publishers in the West and Midwest joined the opposition to what they increasingly saw as an attempt to impose a New York-London publishing monopoly.

\section{International Copyright as a Reform Movement}

The Progressive Era has been called an age of reform, the gilded age, and the age of rebirth after the catastrophic losses of the Civil War. Towards the end of the nineteenth century, Americans experimented with new forms of regulation, child-labor legislation, eight-hour laws, workmen's compensation, juvenile courts and new moral laws, and railroad rate regulation. Copyright reform was part of a larger thrust towards remaking the state regulatory apparatus in order to reflect citizenship and moral concerns. Progressives believed in the formative power of literacy, encouraging civility among the urban masses and often isolated rural dwellers. Citizenship was

32 C.E. Appleton, American Efforts After International Copyright, ForTnIGHT REv., Feb. 1877, at 244.

33 George Haven Putnam, The Position of American Publishers on the Question, PUBLISHER's WKLY., Feb. 10, 1883, at 173. 
predicated upon the diffusion of knowledge - and the proper regulation of copyright either through limiting protection to increase access to books or maximizing protection to ensure the quality of American literary production was seen as essential to this project. Indeed, wrote one observer, international copyright had been given such attention in Congressional hearings and reports that "temperance and tariff seem to have no pre-eminence." ${ }^{34}$

Yet the ideal of disseminating the inexpensive books and journals seen as necessary for the grounding of citizenship entered into conflict with the notion of copyright as a moral system which guards against the theft of mental products. Copyright's failure to protect international authors represented a loss of moral authority. Henry Van Dyke, a minister at New York's well-known Brick Presbyterian Church, wrote of the "sin of literary piracy." The sin

lies in the stupefying fact that ours is the only civilized Christian country on the globe which deliberately and persistently denies to foreigners the same justice which it secures to its own citizens, and declares that the intellectual property of an alien shall be forfeited and confiscated the moment it touches our shore or crosses our border. ${ }^{35}$

"International copyright protection," intoned an article in The Nation, "is simply a question of whether we will be an honest or dishonest nation. ${ }^{136}$ Echoing antislavery and anti-Mormon campaigns, one writer called this situation "a relic of barbarism." ${ }^{137}$ Copyright as the hallmark of civilization, of course, reflected the role of print culture in the mission civilisatrice. By ignoring the protection of foreign authors, legislators showed a "crude, barbarous attitude." 38 "The civilized world ... for half a century has pointed

3425 UNIVERSALIST 93 (1888).

35 Henry Van Dyke, The National Sin of Literary Piracy 14-15 (New York, Charles Scribner's Sons 1888). On the importance of moral discourse for American intellectual property law, see Steven Wilf, The Moral Lives of Intellectual Properties, in TRANSFORMATIONS IN AMERICAN LEGAL HISTORY, supra note 2, at 344. The American Copyright League may have been concerned that their claims of American piracy of the works of British authors might backfire, and therefore published a pamphlet outlining British pirating of American works under existing copyright law. See Brander MatTHews, AMERICAN Authors AND BRITISH PIRATES (New York, American Copyright League 1889).

36 NATION, June 28, 1888.

37 Sarah Barringer Gordon, The Mormon Question: Polygamy and CONSTitutional CONFLict in NinETEENTH-CENTURY AMERICA 55-58 (2002);

CRITIC, Feb. 4, 1887.

38 Christian Union, Feb. 14, 1884. 
the finger of scorn at us for this tolerance of wrong-doing." ${ }^{39}$ Prompted by the signing of the Berne Convention in 1886, President Grover Cleveland pointed to "the drift of sentiment in civilized communities toward full recognition of the rights of property in the creation of the human intellect." 40

To call for the "abolition" of copyright protection solely for domestic authors was powerful language only a generation after the Civil War. Slavery and abolition, of course, were important tropes during this period. The absence of international copyright protection, George Parsons Lathrop claimed, constituted "the worst stain on our national name since that of slavery." 41 One New York proponent of international copyright in 1884 stated that it would be an "honorable reprisal if twenty years after the North had removed the national stain of slavery, the South should be the determining factor in the removal of the national disgrace of literary piracy." 42 The role of authors in calling for the abolition of piracy echoed their social engagement in the cause of abolishing slavery.

Seeing the need for a broad-based organization, authors, publishers, journalists, and other supporters of international copyright formed the American Copyright League in 1883 . While the League began with only thirty or forty members, it consisted of six or seven hundred members by $1884 .{ }^{43}$ It was founded "to urge a reform of American copyright law, and primarily the abolition, so far as possible, of all discriminations between the American and foreign author." 44 Broader calls for reform were soon limited to the bedeviling international copyright issue. ${ }^{45}$ The American Copyright League might well have been inspired by the Association Littéraire et Artistique Internationale, which was founded in Paris by Victor Hugo in 1878 and proved to be a precursor to the Berne Convention. In 1882, a similar association, the Authors' Club of New York, was founded. ${ }^{46}$ But

3928 CENTURy Illustrated MAG. 144 (1884).

40 CRITIC, Dec. 11, 1886.

41 ForUM, July 1886, at 496.

42 CrITIC \& GOOD LiTerature, Mar. 1, 1884. On the relationship between slavery and intangible property which escaped proprietary claims, see STEPHEN M. BEST, THE Fugitive Properties: LaW and the PoEtics of Possession (2004).

43141 N. AM. REv. 349, 606 (1885). The original limited size of the organization might be seen in its founding documents, including its Constitution. See AMERICAN Copyright League, First annual Meeting of the American Copyright League (Held at the RoOms of the Author's Club 19 West 24th St., New York City, November 7, 1885) (New York, American Copyright League 1885).

44 Critic \& Good Literature, Jan. 19, 1884.

45 Critic \& GoOd Literature, Mar. 15, 1890.

46 Carol Ellen Cutler, A History of the American Copyright League 1883-1909 (1973) (unpublished M.A. thesis, University of Chicago) (on file with author). In 1889, 
anyone could join the American Copyright League: technical or imaginative writers, and even non-authors. ${ }^{47}$ The American Copyright League was broad in its membership qualifications, but narrow in determining who held power. The League's constitution vested control in a Council of Thirty - one wonders whether the organizers realized that this echoed the council by the same name which was assigned the task of reforming the Catholic Church in 1542 as a response to the Protestant Reformation. ${ }^{48}$

The American Copyright League operated in a period when citizen intellectual property political action was coming to the fore. In 1890 , for example, the British Society of Authors drafted a copyright bill which was presented to the House of Lords. This bill included provisions for making uniform the copyright term - which up until that time varied depending upon whether the work was a book, painting, or dramatic production - and granting the rights of dramatization to the author, as well as mechanisms established for the seizure of pirated works. ${ }^{49}$ An agrarian movement to transform patent law was forming in the Prairie states at precisely the same time that the American Copyright League was agitating for the reform of copyright throughout the major cities of the Northeast. Criticizing patent as unfriendly to user rights, farmers mobilized against existing patent law within broader agrarian organizations such as the Grange. Numerous petitions for new legislation were sent to Congress and legal defense funds were established to protect farmers against patent infringement suits. ${ }^{50}$ There is no evidence that these two contemporaneous movements - a Progressive urban reform movement to extend copyright and an often radical Populist agrarian movement to curb the reach of patents - were attuned to each other's political campaigns. But both reflected the importance of popular mobilization in framing ideas about intellectual property towards the end of the nineteenth century.

Brander Matthews, who was both a graduate of Columbia Law School and the first American professor of dramatic literature at Columbia College, grounded intellectual property social movements in an evolutionary theory of law similar to those popularized by Henry Sumner Maine. As they become more complex, societies move from tangible to intangible property.

a representative of organized literary life in France spoke at the meeting of the American Copyright League. See CRITIC, Dec. 14, 1889.

47 CRitic \& GoOD Literature, Jan. 19, 1884.

48 CRITIC \& GOOD LITERATURE, Nov. 14, 1885.

49 PUTNAM, supra note 9, at 276-86; SEVILLE, supra. note 12, at 37-38.

50 See Steven Wilf, Patent and Citizen in Late Nineteenth-Century America (Dec. 15, 2009) (unpublished manuscript, on file with author). 
The invention of printing - along with the Reformation and the discovery of the New World - constitutes the grounding for the emergence of modern civilization. According to Matthews, there is an additional significant evolution with the development of "the moral sense of society." A tireless promoter of international copyright, Matthews believed that the purpose of the American Copyright League was to serve as the midwife for changing social norms about literary property: "If public opinion supported the [author's] claim of possession, the claimant would be sustained in his effect to get revenge." ${ }^{51}$

Writers such as Mark Twain, Oliver Wendell Holmes, Henry James, and Edmund Stedman were members of the American Copyright League. In order to dispel a nationalist critique of a movement whose reforms largely would benefit British writers and large American publishers, the movement's public visage was often the American literary figure as domestic artisan. The League collected statements from such figures supporting the idea that "the right of an author to the product of his brain, like the right of the mechanic to the product of his hands, does not depend upon national or geographical conditions." 52 "Authors are laborers," wrote one adherent of international copyright who called for "the legal recognition of brain-work as property."53 To call an organization which included faculty members from Harvard, Yale, Columbia, Princeton, and Johns Hopkins grassroots might be a stretch of any botanical classification system. ${ }^{54}$ But "publishers, paper-makers, and others concerned with the manufacture of books had been asked to join. ${ }^{155}$

Framing and tactics were used to broaden the League's narrow political base. "Help pull down the Black Flag" urged one pamphlet, which was published as the movement lumbered towards successful passage of legislation to protect foreign authors. ${ }^{56} \mathrm{In}$ its pamphlet "Plain Talk to a Professed Pirate," the American Copyright League tried to explain that this issue was not simply a matter of "the clamor of two hundred authors against

51 Brander Matthews, The Evolution of Copyright, 5 POL. SCI. Q. 583, 584 (1890). On the importance of evolutionary thinking in this period, see Steven Wilf, The Invention of Legal Primitivism, 10 THEORETICAL INQUIRIES L. 484 (2009).

52 AMERICAN COPYRIGHT LEAGUE, WHAT AMERICAN AUtHors THINK ABOUT INTERNATIONAL COPYRIGHT 3 (New York, American Copyright League 1888).

53 George Haven Putnam, International Copyright: Considered in SOME OF ItS Relations to Ethics ANd POLitical ECONOMy 3-4 (New York, GP Putnam's Sons 1879).

5428 Century ILlustrated Mag. 144 (1884).

55 CRITIC, Jan. 7, 1887.

56 CRITIC, Mar. 15, 1890. 
the interests of fifty-five million people." All property-owning citizens - an Edison or a farmer or an author - were owed protection against "pillage." Cheap literature was no more an essential right than cheap food; the League wished to promote a national literature that was currently being crowded out by inexpensive reprints of British authors; foreign authors would receive one-third of the money they were currently obtaining through courtesy of the trade. ${ }^{57}$ Such arguments were similar to those employed by property rights advocates in the contemporary United States. "There is only one thing better than a cheap book," declared James Russell Lowell, President of the American Copyright League, "a book [which is] honestly come by." 58 "Nobody ever thinks of robbing a bookseller's store of foreign books," wrote another supporter of international copyright, "but if a foreigner is seen coming into the store with a manuscript, people fall on him and rob him without mercy, and tell him that they were driven to it by hunger for knowledge."59

Not everyone was convinced. International copyright supporters seemed to claim that property rights trumped cheap books for the working poor, although disseminating culture was critical for establishing the underpinnings of America's democracy. Cheap books were the nineteenthcentury equivalent of the access to knowledge movement. Writing to Congressman William Dorsheimer to oppose his attempt to institute international copyright protection, Roger Sherman, a Philadelphia printer, argued,

if you accord to foreign authors the same right in this country that native writers possess, you tax the American citizen for something that he now possesses free, and you deprive the American artisan of the labor which he would be called to perform in the production of these books. ${ }^{60}$

Calling for support of a national literature seemed like a proxy for granting pecuniary advantages to publishers. The popularity of Norwegian ice cream underselling American ice cream makers, one wag suggested, might be addressed by creating a body of ice cream sellers similar to the

57 Henry Holt, Plain Talk to a Professed Pirate, reprinted in CRITIC, Apr. 10, 1886, at 185.

58 BRAnder Matthews, Cheap Books and GoOd Books 3 (New York, American Copyright League 1888) (quoting James Russell Lowell).

59 CRITIC, Feb. 11, 1887; see also CRITIC, Dec. 31, 1887.

60 Roger Sherman, International Copyright: An Open Letter 4 (Philadelphia, Sherman \& Co. 1884). 
American Copyright League. ${ }^{61}$ Anti-international copyright arguments were delegitimized.

Piracy of foreign books is now permitted in the United States, and is not a technical offense. But the man who defends an essential theft because it is easy; because it benefits many at the expense of a few, and is not technically guilt; that man brands himself morally as the felon is branded with hot iron. ${ }^{62}$

Yet there was an underside to the American Copyright League's call for reform. The idea of international copyright was framed within the context of a shared Anglo-American cultural milieu at a time when mass immigration threatened to alter the ethnic composition of the United States. According to Henry James, international copyright was not simply a matter of providing compensation to authors. It would grant access to "the whole body of our English utterance . . . the magnificent library of our race." Russell Lowell, a major figure in the American Copyright League, wrote of "the community of blood, of law, of language, and of books existing between Great Britain and the United States." ${ }^{\text {64 }}$

The conception of an Anglo-American Protestant literary culture spanning the Atlantic existed side-by-side with nationalist American calls for protecting domestic writers from cheap foreign editions. It is somewhat ironic that the international copyright movement had its roots in a distinctly American xenophobic set of claims. E.C. Stedman supported international copyright as a pro-American literary endeavor, claiming "Good, wholesome, home-made bread was better for Americans than French rolls or English muffins." ${ }^{165}$ The steamy novels of Emile Zola represented the sort of French import which might be damaging to American morals. ${ }^{66}$

61 Puck, June 16, 1886.

62 George Parsons Lathrop, Should Foreign Authors Be Protected?, ForuM, July 1886, at 497. Some critics of international copyright denied the idea of a natural right in literary property and the notion of unfettered property rights - especially in light of the limited term for copyright. See 37 Christian UnION 295 (1888).

63 Edwin T. Bowden, Henry James and the Struggle for International Copyright: An Unnoticed Item in the James Bibliography, 24 AM. LITERATURE 537, 537-39 (1953) (quoting Henry James).

64 PutnAM, supra note 30, at 333 (Matthew Brander quoting James Russell Lowell).

65 CRITIC, Mar. 17, 1888.

6637 Christian UNION 295 (1888). In a plea for signatures to petition Congress, Zola's writings were specified as examples of "foreign fiction, un-American, and in many cases undesirable for American readers." "A large portion" of English novels were said to "deal with some tale of seduction." PuTNAM, supra note 9, at 98. 
A cartoon entitled "Criminal Negligence — Wrecked in Port," published in 1887 , chided Congress for failing to protect United States interests. It depicted a ship, "American Literature," going to pieces on the rocks of "Foreign Reading Matter," with only a few surviving passengers and seamen signaling helplessly from the deck. These figures, members of the American Copyright League, including Lowell, Holmes, and Howells, struggle against the seething waters. No flame is lit in the lighthouse of "Encouragement to National Literature." In the "Congressional Life-Saving Station" the rescue boat, labeled "International Copyright," stands idle. Congressmen are sitting about, smoking cigars and playing without concern a game of cards. ${ }^{67}$

The tactics of the League moved away from simply sending memorials to Congress, and instead included hiring a lobbyist, public readings by authors in favor of international copyright, and the establishment of regional copyright leagues. ${ }^{68}$ Public readings took place in such venues as New York's Madison Square Theatre or Chickering Hall. Prior to a lineup of famous and less well-known authors, a pro-international copyright speech might be given by a league supporter such as George William Curtis. These meetings provided an eidetic image of authors lined up in support of the American Copyright League's cause. Since admission was charged for these readings, they raised funds for lobbying as well as consciousness. The authors' readings in Chickering Hall on November 28 and 29, 1887, netted the League almost four thousand dollars. ${ }^{69}$ Access to newspapers, clerics delivering sermons from actual bully pulpits, and publishers printing pamphlets in-house meant that the League was particularly favored in its ability to communicate its message.

The uniting of author, publisher, and reader interests required the performance of a delicate quadrille that sharpened the distinct identities of each of these groups, while simultaneously seeking common ground. Social movements coalesced around the advancement of international protection for authors, which framed the philosophical grounding and policy objectives for the granting of intellectual property rights. At the same time, however, counterarguments were put forth which did not simply respond to the issue of extending rights to foreign authors, but shed doubt upon the very legitimacy of protecting this form of knowledge.

67 Critic, Dec. 10, 1887 (describing TID-BITs, Dec. 3, 1887).

68 Cutler, supra note 46.

69 Critic, Nov. 5, 1887; Critic, Nov. 26, 1887; 32 Publishers' Wkly. 883, 833 (1887). 


\section{Conversion on the RoAd to Berne}

Extra-official mobilization, represented by the American Copyright League, emerged only after numerous diplomatic and legislative initiatives failed to be enacted. In 1878, the Harper Draft Treaty sidestepped Congress by embarking upon diplomatic negotiations for reciprocal copyright protection, which would need to be ratified only after a treaty was signed. The trouble of negotiating a treaty with a foreign country proved as difficult a task as negotiating among American legislators with vastly different sectional and economic interests. As Frederick T. Frelinghuysen, Secretary of State under President Chester Arthur, noted, a formal copyright treaty would need to address the numerous differences in substantive and procedural copyright law. More significantly, it was difficult to bridge the difference between Britain's free-trade stance and America's "Chinese-Wall tariff." ${ }^{70}$ The treaty negotiations floundered because of British opposition to a manufacturing provision, which linked protection to foreign authors with a requirement for printing copies of their works within the borders of the United States. ${ }^{71}$

Frelinghuysen noted that "there seems to be no popular demand for such legislation." 72 The failure to rouse public support would hound the supporters of international copyright as the struggle shifted from diplomacy to legislative initiatives in Congress. But using extra-official proposals posed dangers as well. Robert Pearsall Smith, son of the Quaker head of the Library Company, for example, proposed a scheme for international copyright. A set royalty what might be thought of as a compulsory license - would be paid to the copyright holder by any publisher reprinting an English work. Smith called his plan "royalty without monopoly." It promised to provide both cheap books for Americans and support for British authors. However, major publishers were wary of those devices that would make cheap books a major goal. Under Smith's proposal there would be no exclusive right license to the publication of a book, which might be reprinted any number of times. ${ }^{73}$

Perhaps the attempt that came closest to success was the Dorsheimer Bill, which granted foreigners United States copyright if the President

7029 Century Illustrated Mag. 953, 953-54 (1885); Frederick T. Frelinghuysen, International Copyright, CRITIC \& GOOD LITERATURE, Feb. 9, 1884, at 66.

71 SEVILLE, supra note 12 , at 33-34.

72 CRITIC, Feb. 4, 1887.

73 Robert Pearsall Smith, An Olive Branch: Anglo-American Copyright (n.p., n. pub. 1887); Robert Pearsall Smith, Anglo-American Copyright, 146 N. AM. REV. 67, 67-85 (1888); see also SEVILLE supra note 12, at 27. 
proclaimed that the author's country and the United States provided reciprocal protection. ${ }^{74}$ Introduced in the House of Representatives on January 8,1884 , it avoided the pitfalls of tariff policy. It excluded all questions regarding the tariff and the importation of books and plates. ${ }^{75}$ Proponents of the Dorsheimer Bill ostentatiously declared it to be "an author's bill." ${ }^{76}$ However, the proposed legislation provided only an impaired bundle of rights for foreign authors. Copyright in a foreign work would be limited to twentyfive years, without the privilege of renewal, and would cease upon the death of the author. ${ }^{77}$ Later, the Judiciary Committee would move towards reciprocal rights for foreign authors, granting them the same term and the right to renew copyright as domestic authors. ${ }^{78} \mathrm{~A}$ draft required arrangements to be made by foreign authors for the protection of an American edition within three months of foreign publication, which would tip the bargaining in favor of the American publisher. There was no manufacturing clause. Not surprisingly, the Bill was presented quietly to avoid public scrutiny, and some Congressmen complained of not having a printed draft prior to the beginning of the debate.

The Dorsheimer Bill galvanized the American Copyright League. Up until it was proposed, the organization raised little money, and its treasurer went abroad, leaving one of its founders, George Parsons Lathrop, to pay its expenses out of pocket. "When Mr. Dorsheimer without consulting us," Lathrop recounted, "brought in an international copyright bill in the House, the apathy of my associates had caused me almost to despair. But they were suddenly aroused," until the organization's rolls increased almost tenfold. ${ }^{79}$ The Dorsheimer Bill's failure had an even more important effect. It persuaded supporters of international copyright that they needed an approach which could broaden their constituency:

The American Copyright League is now convinced ... that the whole agitation on the subject of international copyright has hitherto been conducted on a false principle; the effort has always been made to convert the Congressman to the copyright cause, instead of which the effort should have been made to convert the people. ${ }^{80}$

One Connecticut observer noted that the Dorsheimer Bill disappointment

\footnotetext{
74 Seville, supra note 12, at 34.

75 Copyright in America, CRITIC, Apr. 11, 1885, at 177.

76 MEdiCAL NEWS, Apr. 5, 1884.

7713 MUSICAL VISITOR 182 (1884).

78 The Dorsheimer Bill as Amended, 25 PuBlishers' WKLY. 204, 204-05 (1884).

79 George Parsons Lathrop, Notes and Comments I, 141 N. AM. REV. 606, 606 (1885).

80 Copyright in America, supra note 75.
} 
had shifted the American Copyright League from "a sort of club" into a new movement, whose "membership would roll up into thousands and tens of thousands" and include "publishers, authors, printers, compositors, [and] citizens of every degree or occupation. The American Copyright League "intends to use the same means of propaganda which gave success to the old Anti-Slavery Society and to the new Civil Service Reform Association." 81 George Haven Putnam referred to the League's persistent circulation of tracts and the hosting of meetings as "missionary work."

Turning to the public, of course, did not increase the chances for consensus. A number of publishers insisted upon a substantial tariff to discourage foreign competition. But it was difficult to increase the tariff beyond the current exorbitant twenty-five percent. ${ }^{83}$ Members of the reading public clamored for an end to the cost of importing foreign books, which impeded cultural exchange. An 1888 article warned about a "book trust." Publishers, it claimed, would use the extension of copyright to foreign authors as a means to raise tariffs and to end access to cheap ooks. ${ }^{84}$ The periodical and pamphlet battle over international copyright relied upon an increasingly rarified group of polemicists. Scholars, who operated in a transatlantic literary world, supported few import barriers while the owners of large publishing houses saw mechanisms such as tariffs as critical to fostering a domestic publishing industry. Yet their interests as consumers often conflicted with their own stake in the issue as producers. Absent international copyright, American authors were subject to the republication of their books abroad without compensation. While the international copyright debates often occurred on the level of theory - are property rights in intangibles analogous to a stake in real property? - posed the problem of American literary culture, and championed the democratic character of print, the fact is that its polemicists always feared they would be viewed as arguing for vulgar economic self-interest.

Perhaps there is no better example of the splits engendered in the American Copyright League than the case of Henry Charles Lea. A leading member of the League, he nevertheless opposed the proposed Dorsheimer Bill as potentially harmful to the book trade. More importantly, he worried about the "spectacle of five hundred American writers forming a league or trade-union for the purpose of obtaining certain legislation, retaining a professional gentleman as a lobbyist in Washington, and refusing to regard any proposition

81 Id.

82 George Haven Putnam, Memoirs of a Publisher 1865-1915, at 374 (1915).

83 NATION, June 28, 1888, at 522.

84 SCIENTIFIC AMERICAN, May 19, 1888, at 304. 
in favor of the public save as an infringement on the imprescriptible rights of property." ${ }^{85}$ Lea broke with many of his closest colleagues in the American Copyright League over the Dorsheimer Bill. Comparing himself to Cassandra, Lea warned that when the public discovered how much the cost of books would rise, it would "sweep away all international copyright . . . [and] wipe out literary property altogether." 86 Proponents of the Dorsheimer Bill accused Lea of fear-mongering, and being subject to the "cheap book delusion." ${ }^{87}$

The pamphlet and newspaper war which erupted around Lea darkly suggested a split between Philadelphia and New York League supporters. Fault lines existed in the very conception of copyright. Is copyright a common carrier? Do limitations on property, such as those requiring innkeepers to provide lodging at a reasonable cost, also apply to authors? Do authors have a fundamental natural right in their creations? Or, alternatively, is copyright a monopoly established through positive law? Lea's arguments were grounded on a particular conception that "the public has rights as well as the author." 88 In the United States, Lea argued, affordable books "are a necessity with all classes. ${ }^{189}$ One American Copyright League supporter, T.R. Lounsbury, declared Lea's arguments - and all claims of the cheap literature movement — "a concession to the meanest form of communism." The League would have to contend not only with the black flag of piracy, it seems, but with the red flag as well.

Lea insisted upon the idea of American manufacture as a prerequisite for international protection. The Dorsheimer Bill had uncovered the fault lines among different groups involved in the book trade. In 1887, publishers founded their own American Publishers' Copyright League, more a trade association than a popular movement. ${ }^{91}$ Increasingly, tensions had been building between publishers - who claimed to represent authorial interests - and flesh and blood authors themselves. In a cartoon entitled,

85 Henry C. Lea, International Copyright, EvenING Post, Mar. 1, 1884.

86 Id.

87 Id.

88 Letter from Henry C. Lea to Samuel J. Randall, International Copyright, an Open Letter 1 (Feb. 18, 1884) (on file with the Lea Papers, University of Pennsylvania).

$89 I d$. at 5 . Lea argued that the interests of authors, those in the domestic printing trade, and readers might be served through either a manufacturing clause or a compulsory license which would allow United States publishers to reprint British books at set royalties. The latter was less attractive to Lea because it would require a collection agency.

90 T.R. Lounsbury, Prof. Lounsbury's Reply to H.C. Lea, 25 PuBLISHERS' WKLY. 270, 270-72 (1884).

91 CRITIC, Jan. 7, 1887. 
"The Millennium for American Authors," printed in the same year, publishers' offices were shown tumbling into the street while jubilant authors hawked their own books. ${ }^{92}$ The Typographic Union became increasingly vociferous about the need for a manufacturing clause. After the failure of earlier legislative attempts, Lea wrote in a letter,

Senator Chace of Rhode Island, a shrewd honest Quaker, had become interested in the subject. He came to Philadelphia in search of information and was referred to me. We took a liking to each other; he soon came to regard me as an authority on the subject, and made up his mind to devote himself to it, which he did with a single-minded earnestness deserving of all praise..$^{3}$

\section{Negotiating Copyright}

After nearly sixty years of agitation on the issue of international copyright, the United States Congress passed the International Copyright Act of 1891, more commonly known as the Chace Act. Even the last act of the quest to protect foreign authors was filled with drama. While Chace's bill passed the Republican Senate on May 9, 1888, it stumbled in the Democratic House of Representatives. ${ }^{94}$ The Chace Act would only be passed on March 3, 1891, when the Republicans, who won more Congressional seats as the protectors of American manufacturing, would regain control of the House. As might be imagined, it was an occasion for a great deal of - perhaps too much - self-congratulation. When President Benjamin Harrison signed the Chace Act into law, he used a quill pen made of a feather plucked from an American eagle. ${ }^{95}$ This was fitting. For America's move to protect foreign authors had its origins in Clay's conception of copyright as the sinews of a national culture, and came to its fruition under the stewardship of the American Copyright League, which argued that international copyright was essential to preserve America's moral stature. Moreover, providing copyright to British authors would shift publishing away from cheap reprints of foreign

92 Critic, Jan. 7, 1887 (discussing LiFE, Jan. 5, 1887).

93 Letter from Henry C. Lea to W.E.H. Lecky (Jan. 7, 1890) (on file with Lea Papers, University of Pennsylvania).

9419 CONG. REC. 3882 (1888); H.R. REP. NO. $50-2311$ (1888).

95 U.S. Copyright Office, Copyright Lore (Oct. 2003), http:/www.copyright.gov/ history/lore/2003/oct03-lore.pdf; International Copyright Act of 1891, ch. 565, 26 Stat. 1106. 
works to promising American writers. Perhaps embracing Americanism in light of his own people's ethnic stereotype, an editorialist for the Jewish Messenger wrote of the end of "cheap reprints of flashy foreign writers."96 "Civilization itself takes a long stride forward," wrote one of its supporters about the passage of the Chace Bill, "in the newly accomplished recognition of intellectual property over the entire globe."197

Remarkably, the author of the Chace Act was not a lawyer or a legislator, but Henry Charles Lea. Perhaps the country's leading medieval historian, Lea was a scholar at the University of Pennsylvania, and his work on the Spanish Inquisition provided a seminal study of archival sources. It also reflected his deep suspicion of Catholicism. Nevertheless, it would be difficult to imagine a better figure to embark upon the complex negotiations involving international copyright. Lea was deeply interested in the international copyright question both as a publisher and scholar, and as a protectionist and political reformer. More importantly, his background suggests overlapping interests. A grandson on his mother's side of Mathew Carey, a Philadelphia publisher and partner of Benjamin Franklin, he might be said to have been from the printing aristocracy. Founded in 1829, the firm of Carey and Lea became one of the country's leading publishing houses, the publisher of James Fennimore Cooper, a leading early advocate of international copyright protection, and Sir Walter Scott. Henry Charles Lea was intimately involved in the family's publishing business.

On the other hand, Lea was also was one of the leading purchasers of foreign books. His immense library, which now belongs to the University of Pennsylvania, included volumes collected from all over the world. As a publisher he favored a high tariff, although as a collector he would have benefited from lower imposts on books. Lea was also a good government reformer. A Mugwump, he opposed the spoils system of appointment and promoted civil service reform. Lea was a leading figure in the Industrial League who promoted the interests of Northeastern manufacturing producers, including publishers. He backed stiff tariff protection of American industries. Even Lea's Anglo-Saxon prejudices, grounded in the sense of a common English language tradition, neatly comported with his commitment to international copyright. Lea's multiple roles as publisher and scholar, protectionist and reformer, coalesced in the international copyright debate. In the words of one observer, "after a series of unsuccessful attempts to reach a settlement on the basis of abstract rights," such as the Dorsheimer

96 Critic, Jan. 28, 1887 (quoting JewiSh MESSENGER).

97 INDEPENDENT, Dec. 11, 1890. 
Bill, Lea's efforts were directed towards practical compromise rather than moral issues. ${ }^{98}$

Lea's drafting of the bill resembled the sort of interest group negotiations which, as we shall see, characterized the later drafting of the 1909 Copyright Act. Indeed, the draft international copyright legislation was presented to the American Copyright League, the American Publishers' Copyright League, and the Typographical Union for amendment. ${ }^{99}$ By the time the Chace Bill was before both Houses, it received the support of both the American Copyright League and the American Publishers' Copyright League, the United Typothetae - which represented the printers, the Typographical Union, the American Newspapers' Publishers' Association, the National Educational Association, the Western Association of Writers, the Boston Copyright Association, the Washington Copyright Association, and the Chicago Copyright League. ${ }^{100}$

Lea secured the agreement of labor to the proposed legislation through balancing these competing interests. Lea himself represented the protectionist interest of the book publishing industry. The American Copyright League, which already had witnessed the failure of the two earlier bills which they supported, was desperate to meet the demands of authors for international copyright protection. Many authors were displeased with raising any issue beyond a straightforward extension of copyright. Nevertheless, the Chace Bill was their only chance for success. Chace was so impressed with Lea's efforts that he wanted to rename the legislation the "Lea Bill." Yet not all interest groups were represented. As one observer tartly noted, during the negotiations "the foreign authors - in whose behalf the international copyright agitation is supposed to have been created - had not a single representative present." ${ }^{101}$ British publishers were disadvantaged by the inclusion of the manufacturing clause in the proposed law. They launched a lobby to defeat the law, but the Chace Bill ultimately passed in $1891 .^{102}$

Were the cobbled together provisions of the Chace Act permanent fixtures of American copyright law? Publisher George Haven Putnam, one of the foremost advocates of international copyright, expressed the hope that "hampering conditions and restrictions would doubtless be removed in a few years' time." 103 For those, like Putnam, who envisioned a world of

\footnotetext{
9837 Century Illustrated Mag. 474 (1889).

99 CRITIC, Mar. 3, 1888.

100 CRITIC, May 15, 1890.

101 NATION, June 28, 1888.

102 Edward Sculley Bradley, HeNry Charles Lea: A Biography 226-31 (1931).

103 Putnam, supra note 9, at iv. Publisher Charles Scribner also opposed the
} 
copyright without borders, the manufacturing clause seemed like an atavistic provision tucked into the otherwise largely forward-looking international copyright statute. The irony was that America had finally turned its back on piracy and passed the Chace Act just a few years after the creation of the Berne Convention for the Protection of Literary and Artistic Works in 1886. What would have looked like a major achievement for international copyright now seemed instead a truncated, halfhearted move towards "the abolition of political boundaries for literary property. ${ }^{104}$

By including a manufacturing provision, the Chace Act garnered the support of paper-makers, type-founders, compositors, printers, binders, and a few publishers who secretly felt threatened by international copyright. ${ }^{105}$ Seeking to construct as broad a coalition as possible, Lea could have envisioned artisan printers as makers of books as readily as authors. But, unfortunately, the manufacturing provision was presented as a political compromise, not as a redefinition of proprietary rights to include stakeholders beyond authors. This left the Chace Act's manufacturing clause open to the accusation that it was a "mortgage" on authors, pure "selfish-greed," a "nefarious scheme" which "implicitly sanctions the fundamental principle of socialism." 106

But even as the manufacturing clause placed printer craftsmen at the constitutive core of copyright, their trades were undergoing a rapid decline in power. Printers were organized under the International Typographical Union (ITU), which was founded in 1852. By the end of the century, however, emerging rivalries led to the appearance of distinct national organizations for electrotypers and stereotypers, bindery works, pressmen and their assistants, copyeditors, and photoengravers. In 1890, mechanical typesetting was introduced. With increasing mechanization, semi-skilled

manufacturing clause. See American Copyright League, An Argument in Favor of an International Copyright, as Proposed by Senate Bill No. 191 AND H.R. BILL No. 2493, at 10-11 (1882).

104 PUTNAM, supra note 9, at xix. Putnam may have been overly optimistic. The United States did not become a signatory to the Berne Convention until the passage of the Berne Convention Implementation Act, 1989, Pub. L. No. 100-568, 102 Stat. 2857 (1988) (codified as amended at 17 U.S.C. $§ 405$ (a) (2000)). On British responses to the broader possibilities of Berne, see BRAD SHERMAn \& Lionel BENTLY, THE MAKING of MODERN INTEllectual Property LAW: The British EXPERIENCE, 1760-1911, at 124 (1999).

105 George Parsons Lathrop et al., Notes and Comments, 141 N. AM. REV. 606 (1885).

106 An Equitable International Copyright Law, 129 WeStMInSTER Rev. 405, 425 (1888) (also published as a separate volume). 
laborers, who simply had to press keys on a linotype to produce a line of print, displaced skilled composition workers. ${ }^{107}$

America's leading publishers remained steadfast opponents of the manufacturing clause. At first glance, this might seem somewhat puzzling since they also would benefit from obligating foreign authors to print their books within the United States. From 1864, however, publishers depended upon an exorbitant ad valorem tariff of twenty-five percent on imported books to protect America's book manufacturers against foreign, namely English, competition. ${ }^{108}$ Responding to calls for exceptions, Congress exempted importers of books in print for more than twenty-years, foreign language books, volumes purchased for libraries and academic institutions which had been in use for one or more years, and books brought from abroad for personal use from paying this duty. ${ }^{109}$ Since older books were published by less established publishers and foreign language books were printed by those catering specifically to niche markets, neither of these exemptions altered the fact that the leading publishing houses were shielded from British competition. Opposing the manufacturing clause, one publisher suggested that such a requirement had no connection to copyright, and that the prohibition against books printed abroad might simply be moved from the Chace Act to tariff legislation - like the banning of the importation of obscene literature. ${ }^{110} \mathrm{In}$ short, this was a suggestion that artisans could use the same sort of legerdemain as publishing houses. Publishers were able both to claim a role as advocates of international copyright and, at the same time, to promote a protectionist tariff that prevented foreign publishers from capturing the burgeoning American market.

As himself the embodiment of so many strains of late nineteenth-century political thought, Lea proved to be the perfect ombudsman to negotiate copyright settlement among different constituencies. The ultimate success of international copyright after so many failures may have led to this new way of seeing the stakeholders as competing interest groups. Could this model be used for the next step in copyright reform? By the beginning of the twentieth century, there was a growing dissatisfaction with American copyright law. Although there was now protection for foreign authors, the American manufacture requirement was cumbersome. New technologies in

107 Jacob Loft, The Printing Trades 37-58 (1944).

108 Act to Increase Duties on Imports, and for Other Purposes, ch. 171, 13 Stat. 202, 213 (1864); Donald Marquand Dozer, The Tariff on Books, 36 Miss. VALlEy HisT. REV. 73, 94 (1949).

109 McKinley Tariff Act, ch. 1244, 26 Stat. 567, 604 (1890).

110 Putnam, supra note 9, at 173-74. 
music were posing challenges to existing doctrine. There were concerns about the difficulties of requiring formalities as a requirement for copyright.

\section{The 1909 Copyright Act And the Rise of Interest Politics}

In his 1909 State of the Union Address, President Theodore Roosevelt, who prior to his presidency had been a member of the American Copyright League, declared that "our copyright laws urgently need revisions." "They omit," he stated,

provision for many articles which, under modern reproductive processes are entitled to protection; they impose hardships upon the copyright proprietor which are not essential to the fair protection of the public; they are difficult for the courts to interpret and impossible for the Copyright Office to administer with satisfaction to the public.

Roosevelt rejected the idea of further piecemeal legislative reform. Instead, he called for a "complete revision . . . to meet modern conditions."111 Roosevelt's reasons for pursuing the passage of a new copyright statute - the rise of new technologies and the difficulty of administering copyright's existing legal framework — operated within the skein of the his administration's larger goals. Copyright represented the use of ingenuity and industry to benefit society, which was an overarching theme of Roosevelt's State of the Union Address. Moreover, Roosevelt pointed out that Germany, Austria, and Sweden had already revised their copyright statutes. A new copyright statute was pending in England. ${ }^{112}$

By the beginning of the twentieth century, changing America's copyright law was clearly on the reform agenda. It was no longer a matter of a single issue, such as the failure to provide international copyright protection, which led to growing calls for a new statute. There was a sense that American copyright had failed to keep pace with a rapidly developing country. The American Copyright League tried, though unsuccessfully, to begin addressing new issues on copyright such as the length of its term. ${ }^{113}$

111 III State OF THE UNION MESSAGES OF THE PRESIDENTS 1790-1966, at 2182 (Fred L. Israel ed., 1966). On President Roosevelt's membership in the American Copyright League, see Brander Matthews, The American Future and Other Essays 273 (1909). Similarly, the British 1911 Copyright Act was intended to consolidate and simplify earlier legislation, see SHERMAN \& BENTLY, supra note 104, at 135.

112 III State OF THE UNION MESSAges OF THE PRESIDENTS 1790-1966, supra note 111, at 2182 .

113 DEAL, Dec. 16, 1908 (suggesting that "[t]he American Copyright League may have 
Indeed, a stated purpose of the League was "to amend and consolidate the law of domestic copyright." ${ }^{114}$ But so much of its energy had been invested in international copyright and it still was committed to ensuring international protection for authors - "so that international copyright might become a practical as well as a theoretical achievement."115

In every annual report from 1901 through 1904, Thorvald Solberg, the Register of Copyright, underscored the need for broad statutory revision. ${ }^{116}$ A new conception of copyright had emerged - the idea that it stood at the crossroads of competing interest groups. George Haven Putnam, a leading publisher and past advocate of international copyright, lobbied for the framing of a new copyright act by a commission of "representatives of the several interests to be considered." In addition, he proposed that "it may be in order to add some representative of the general public." ${ }^{117}$ Putnam's vision of a copyright commission composed of interest groups reflected Progressive Era valorization of expert authority. By being vested with the power to summon witnesses and provided the time to master the details of copyright, the commission would embody "expert training and expert experience" in its recommendations for a new law. ${ }^{18}$

This proposal was realized when Herbert Putnam, the Librarian of Congress and the brother of George Haven Putnam, and Thorvald Solberg, the Register of Copyrights, at the end of May 1905 gathered together various interest groups to discuss drafting a new copyright statute. Although representatives from approximately thirty organizations were invited to meet for a series of conferences which were held in 1905 and 1906, there was despite the suggestion in the original proposal - no one to speak for the public. Instead, the site of the meetings, the New York City Club, reflected the tightly knit social world of urban copyright lobbyists. Housed in a Fifth Avenue mansion with floors of inlaid wood, the New York City Club was dedicated to the principles of good government. ${ }^{119}$ New York itself was the literary and musical industry capital of the United States, and the intent was

seemed moribund" except for continuing lobbying for extending the copyright term).

114 CRITIC, July 21, 1888.

1151266 PuBLISHERS' WKLY. 767 (1896).

116 U.S. Gov't Printing Office, The History of U.S.A. Copyright LaW Revision FROM 1901-1954: STUDiEs PREPARED FOR THE SUBCOMMITTEE ON PATENTS, TRADEMARKS, AND COPYRIGHTS 1 (1955).

117 PUTNAM, supra note 9, at xi-xii.

118 Id. at xii.

119 N.Y. TIMES, Oct. 3, 1892. 
to hear from the various interest groups who were stakeholders in copyright. This represented a remarkable shift. Copyright had become too complex, too fraught with interlocking interests, for drafters to move forward without broadly consulting those most involved. The list of delegates is telling. ${ }^{120}$ Authors, represented by the American Copyright League, and publisher trade associations such as the American Publishers' Copyright League, of course, were present. The names of the publishers, William W. Appleton, George Haven Putnam, and Charles Scribner, were prominently displayed. All of these individuals had been vocal in the national debates over copyright. ${ }^{121}$

But it was striking that so many associations had grown up around copyright. As we have seen, international copyright issues mobilized authors and publishers, and led to the creation of various organizations. Some of the gathered delegates stood as representatives for various forms of expression: architecture (Architectural League of America), advertising (International Advertising Association), and magazines (Periodical Publishers' Association of America). Some groups, such as the National Academy of Design, were still waiting for full-scale intellectual property protection. The numerous and varied forms of expression represented - architecture, theater, music, sculpture, and photography - suggested how difficult it would be to determine one unified standard for different subject matter of copyrightable works. These twenty-five delegates did not simply represent the producers of creative industries. The American Bar Association, which spoke for lawyers involved in copyright cases, and the American Library Association were also present.

The idea of a miniature legislature to debate copyright was meant to sidestep the actual legislature of Congress. Mobilizing public support for the passage of new laws protecting authors' rights might lead to a diminution of copyright protection. George Haven Putnam expressed dissatisfaction with the current state of copyright, but believed it was "unwise" to press for change since

the public opinion which creates and directs legislative opinion is not yet sufficiently assured in its recognition of the rights of literary

120 The invitee list for the Conference on Copyright (New York City, May 31-June 2, 1905 ) is reprinted in 1 THE LEGISLATIVE HISTORY OF THE 1909 COPYRIGHT ACT, at iii-vi (E. Fulton Brylawski \& Abe Goldman eds., 1976). JESSICA LITMAN, DIGITAL COPYRIGHT 38-40 (2001) identifies the making of the 1909 Copyright Act with the beginnings of negotiated compromises for copyright law applying to a variety of industries.

121 INDEPENDENT, Jan. 5, 1888. 
producers, to be trusted to take an active or intelligent interest in securing more satisfactory protection of such producers. There would be a grave risk that, if the copyright question were reopened in the present Congress, we might, in place of developing or improving the copyright system, take a step backward . . . ${ }^{122}$

At that time, the skilled craftsmen who worked in the publishing trade were considered stakeholders, and the representatives of typographers and lithographers participated in discussions. Their interests were embodied in the mechanical work clause, Section 15, of the 1909 Copyright Act. A direct descendant of the manufacturing clause, this provision required that books receiving copyright protection must be printed in the United States or from plates typeset within the United States. Yet the idea that craftsmen who make the tangible written work have claims as well as the authors of expression would ultimately disappear from copyright law. ${ }^{123}$

Perhaps the most puzzling entry in the list of delegates is the last one: The Sphinx Club. The club, founded in 1896, represented a small group of advertising and business executives with Progressive ideals. The Sphinx Club looked towards bringing a sense of professional responsibility to this burgeoning field. It established the first courses in advertising offered at a university, would later create a "truth in advertising" standard, and through a Vigilance Committee, which would ultimately evolve into the Better Business Bureau, set forth self-regulating mechanisms to ensure ethical conduct. In many ways, the Sphinx Club resembled convivial educational societies from the early nineteenth-century. The focus, however, was upon issues of trade knowledge. Although the Sphinx Club was fairly small, the organizers may well have been trying to tilt the discussion in the direction of drafting a statute which represented Progressive notions of responsibility. No one spoke directly for the public interest. ${ }^{124}$

Each association represented competing business interests. The American Copyright League bluntly proposed that "the copyright term should be as long a period as possible," and recommended that the duration of protection be extended to "the life of the author and fifty years thereafter." ${ }^{25}$ It also

122 PUTNAM, supra note 9, at 172.

123 Copyright Act of 1909, ch. 302, $\S 15,35$ Stat. 1075, 1078-79. At the insistence of the Typographical Union, the United States Commissioner of Labor instituted a full report on the economic and labor impact of the Chace Bill. See REPORT OF THE Proceedings of the International Typographical Union (46Th Session) 118 (1900).

124 SPHINX CluB 7-9 (1904).

125 Stenographic Report of the Proceedings of the First Session of the Conference on 
proposed that the government's share of half the penalty recovered in cases of copyright infringement be removed from any new statute, separate clauses be drafted for each different sort of work - such as dramatic works or literary works - and that provision be made to protect authors who inadvertently fail to meet formality requirements against the forfeiture of copyright. Since sheet music is comparatively shorter than books, the music publishers claimed that they had a larger problem with intellectual property piracy than any other trade. They demanded stiffer penalties against pirates. ${ }^{126}$ Established through the efforts of the Aeolian Company, a leading maker of player piano rolls, the American Musical Copyright League claimed the mantle of earlier copyright associations and sought to be seen as operating for the public good. Yet contemporary observers noted that this new copyright league was simply "organized from selfish reasons" to lobby for business interests. ${ }^{127}$ Echoing the idea that copyright is identified with the public good, Richard Rogers Bowker, a leading copyright expert, bluntly stated that the American Musical Copyright League "should rather be called an anti-copyright league." 128

The American Copyright League and other Progressive Era copyright associations always were grounded upon a mix of moral reform and self-interest. Drawing upon their access to print media, they appealed to broad constituencies, but organizational power was retained by economic and intellectual elites. As social movements, copyright associations used grassroots tactics, promoted a vision of copyright as a system founded upon justice, and mobilized urban citizens in the cause of legal reform. In the end, however, the negotiated settlement which achieved international copyright protection revealed the interest groups with stakes in proprietary models of regulating knowledge. Ironically, authors acting through collective action paved the way for the construction of interest groups as the foundation of the 1909 Copyright Act and its progeny until our own times.

\section{Literary Culture Without Borders}

To promote the progress of science and the useful arts begs the question: promote for whom? In many ways, the public good was implied in the

Copyright Held at the New York City Club, New York, N.Y., May 31-June 2, 1905, reprinted in 1 LEGISLATIVE HISTORY OF THE 1909 COPYRIGHT ACT, pt. C at 7 (Fulton E. Brylawski \& Abe A. Goldman eds., 1976).

$126 \mathrm{Id}$. at 12.

127 Publishers' WkLY., Nov. 3, 1906, at 1252.

128 Richard Rogers Bowker Papers, Box 84, New York Public Library. 
Constitutional Copyright and Patent clause. It was, however, only realized over time through a set of conflicts, negotiations, and ad hoc calls for legal change. The history of intellectual property law can be seen as reflecting an ever-expanding galaxy of subject matter, term, and policing mechanisms. Yet this would be like watching a Punch and Judy show with only Punch. The fact is that recourse to public mobilization entered debates about the scope of intellectual property law fairly early, and reached its apotheosis with the creation of copyright social movements in the end of the nineteenth century. Sometimes this meant calling for its extension - as was the case with international copyright protection for foreign authors; sometimes this meant claiming users' rights, as with the cheap book movement; and sometimes this meant rethinking the identity of creators, as with the protection of printer rights under the mechanical clause.

The movement for international copyright stretched the idea of copyright to include these conceptions and moral visions, and even identified a pan-Anglo-American literary culture. Framing arguments in a sophisticated fashion was less important for movement participants than realizing political goals - but framing served to construct self-conscious notions of copyright. In the end, the campaign for international copyright prompted the emergence of a new, interest groups-based understanding of copyright legislative change - and these interest groups ultimately would embrace a proprietary model. ${ }^{129}$

The focus on the public good so prevalent among associations, such as the American Copyright League, which battled for international copyright protection, was transformed into interest group politics by the time of the drafting of the 1909 Copyright Act. Grass-roots mobilization, ironically, led to the staking out of positions among different economic interests. Even the great achievement of the late nineteenth-century copyright social movements, the passage of the Chace Bill after fifty-four years of agitation for international copyright, was not as clear a victory as first appears. With still greater irony, the United States adoption of the manufacturing clause prompted a backlash in the international copyright community. The Berne Union adopted a protocol in 1914 that allowed member states not to protect

129 For a particularly thoughtful discussion of the tension between copyright as a right and the process of negotiating legislative action, see Jessica D. Littman, Copyright, Compromise, and Legislative History, 72 CORNELL L. REV. 857, 857 (1987). Steven Wilf, The Making of the Post-War Paradigm in American Intellectual Property Law, 31 COLUM. J.L. \& ARTS 139, 205 (2008), focuses upon the intersection of citizenship and economics in the creation of a New Deal model of intellectual property protection. 
United States works even if these were first published in their territory. By the time of World War I, American participation in the Berne Convention seemed more elusive than ever. ${ }^{130}$

Perhaps this narrative provides a lesson for our own times. Absent a coherent framework reconceptualizing intellectual property's fundamental principles, all social movements will be co-opted. Pirate parties and creative commoners need to think about the justifications for intellectual property, the terms of a new framework for norms, and how this might be implemented. For any social movement, the question is what will happen when the immediate cause prompting collective action disappears. Will the pirate parties survive the resolution of the legal status of peer-to-peer file sharing? What legacies can be constructed from contestation over intellectual property norms? This Article offers an antidote to the reified narrative of authorship, the turn to culture in academic intellectual property law, by making a turn to the contingent, surprising, and deeply contested terrain of history. In the end there must be a turn to a deeper understanding of how historical actors have sought to recast the contours of intellectual property law.

These actors, both those operating within and outside of official capacities, frame ideas, mobilize constituencies, set forth ideals - which might well be sacrificed within negotiated settlements. Expending vast mental resources in creating alternatives to existing intellectual property rules, social movements are significant for the possibilities they raise, if not for their ultimate success in securing their adoption. The unsettling of official legal categories is itself a useful art.

130 Additional Protocol to the International Copyright Convention of November 13, 1908, Mar. 20, 1914, 1 L.N.T.S. 243; see Daniel Gervais, The 1909 Copyright in International Context, 26 SANTA CLARA COMPUTER \& High TECH L.J. 185, 195 (2010). W. Boyd Rayward, Manufacture and Copyright: Past History Remaking, 3 J. LiBR. HIST. 7, 13 (1968), describes the post-1909 struggle to reduce the power of the manufacturing clause to overcome barriers to international protection. 